\title{
Gorontalo
}

Accounting Fournal

Vol. 4 No. 1 April 2021

P-ISSN: 2614-2074, E-ISSN: 2614-2066

Nationally Accredited Journal, Decree No.36/E/KPT/2019

\section{COMPANY SIZE, FINANCIAL DISTRESS AND AUDIT COMPLEXITY AGAINST AUDIT REPORT LAG UKURAN PERUSAHAAN, FINANCIAL DISTRESS DAN AUDIT COMPLEXITY TERHADAP AUDIT REPORT LAG}

\author{
Baiq Fitri Arianti \\ Program Studi Akuntansi, Fakultas Ekonomi, Universitas Pamulang \\ Jalan Surya Kencana No. 1 Pamulang Barat, Tangerang Selatan \\ email: dosen00862@unpam.ac.id
}

Submit : 2020-12-01; Revision : 2021-04-02; Publish : 2021-04-06 Gorontalo Accounting Journal, 4(1): 41-56

\begin{abstract}
The purpose of this study is to measure and test the company size, financial distress, and audit complexity on audit report lag either partially or simultaneously. The type of research used is quantitative research with associative methods. The sample method in this study used a purposive sampling technique with a total sample of 7 miscellaneous industry sector companies and petroleum and natural gas obtained from the annual report for 5 years of observation as many as 35 annual reports 2015-2019. The data analysis technique used in this research is descriptive statistical analysis, classical assumption test, multiple regression test, and hypothesis testing with the help of the SPSS version 25 software program. The results of this study indicate that partially company size affects the audit report lag, financial distress variables. it does not affect the audit report lag, and audit complexity has an effect on the audit report lag. Meanwhile, the simultaneous test shows that all independent variables affect the audit report lag.
\end{abstract}

Keywords: Company Size; Financial Distress; Audit Complexity; Audit Report Lag

\begin{abstract}
Abstrak
Penelitian ini bertujuan untuk mengetahui pengaruh ukuran perusahaan, financial distress, dan audit complexity terhadap audit report lag baik secara parsial maupun simultan. Jenis penelitian yang digunakan adalah penelitian kuantitatif. Metode sampel dalam penelitian ini menggunakan teknik purposive sampling dengan jumlah sampel 7 perusahaan sektor aneka industri dan subsektor minyak dan gas bumi yang didapat dari annual report selama 5 tahun pengamatan sebanyak 35 annual report tahun 2015-2019. Teknik analisis data yang digunakan dalam penelitian ini adalah analisis statistik deskriptif, uji asumsi klasik, uji regresi berganda, dan uji hipotesis dengan bantuan program software SPSS versi 25. Hasil penelitian ini menunjukkan bahwa secara parsial ukuran perusahaan berpengaruh terhadap audit report lag, variabel financial distress tidak berpengaruh terhadap audit report lag, dan audit complexity berpengaruh terhadap audit report lag. Sedangkan untuk uji simultan menunjukkan bahwa semua variabel independen berpengaruh terhadap audit report lag.
\end{abstract}

Kata Kunci: Ukuran Perusahaan; Financial Distress; Audit Complexity; Audit Report Lag 


\section{PENDAHULUAN}

Laporan keuangan merupakan hasil akhir dari serangkaian proses pencatatan dan pengikhtisaran data transaksi bisnis yang memberikan informasi keuangan suatu perusahaan yang berguna bagi pihak internal maupun eksternal perusahaan. Menurut PSAK 1 (2015:1.3) laporan keuangan adalah suatu penyajian terstruktur dari posisi keuangan dan kinerja keuangan suatu entitas. Auditing memberikan nilai tambah bagi laporan keuangan, karena akuntan publik sebagai pihak yang dianggap ahli dan independen pada akhir pemeriksaannya akan memberikan pendapat mengenai kewajaran posisi keuangan, hasil usaha, perubahan ekuitas, dan laporan arus kas. Auditing laporan keuangan terdiri dari upaya memahami bisnis dan industri klien serta memperoleh dan menilai bukti yang berkaitan dengan laporan keuangan, sehingga memungkinkan auditor meneliti apakah pada kenyataannya laporan keuangan tersebut telah menyajikan laporan keuangan secara wajar sesuai dengan Prinsip Akuntansi Berterima Umum (PABU) (Mayangsari dan Wandanarum, 2013:10).

Berdasarkan Peraturan Otoritas Jasa Keuangan Nomor 29/PJOK.04/2016 tentang penyampaian laporan keuangan, emiten atau perusahaan publik wajib menyampaikan laporan tahunan kepada otoritas jasa keuangan paling lambat pada akhir bulan keempat setelah tahun buku berakhir. Tuntutan akan kepatuhan terhadap penyampaian laporan keuangan tahunan perusahaan publik di Indonesia telah diatur dalam Undang-Undang Nomor 8 Tahun 1995 tentang pasar modal diikuti dengan Peraturan Nomor X.K.2 lampiran ketua Bapepam-LK Nomor : KEP-36/PM/2003 tentang kewajiban penyampaian laporan keuangan berkala.

Rentang waktu penyelesaian audit yang dilakukan terhadap laporan keuangan dapat mempengaruhi ketepatan waktu informasi tersebut dipublikasikan dan sebagai pengambilan keputusan. Kendala yang diakibatkan proses audit ini disebut audit report lag atau dalam penelitian lain dinyatakan dengan audit delay (Didipu, 2016). Menurut penelitian Irviona dan Basuki (2017), audit report lag (ARL) adalah waktu yang dibutuhkan untuk menyelesaikan pekerjaan audit sampai pada tanggal dipublikasikannya laporan audit perusahaan, yang diukur berdasarkan jumlah hari yang dibutuhkan untuk memperoleh laporan auditor independen, terhitung sejak tutup buku yaitu per 31 Desember sampai pada tanggal yang tertera pada laporan auditor independen.

Fenomena dalam penelitian ini mengenai PT Nipress Tbk (NIPS) yang belum menyampaikan laporan keuangan perusahaan periode 31 Desember 2018 yang seharusnya dilaporkan paling lambat 30 April 2019. Berdasarkan pemantauan Bursa hingga 29 Juli 2019 PT Nipress belum menyampaikan laporan keuangan interim. Sehingga Bursa melakukan suspensi dengan merujuk pada ketentuan II.6.3 Peraturan 1-H: Tentang Sanksi, Bursa telah memberikan peringatan tertulis III dan tambahan denda sebesar Rp150.000.000,00 kepada perusahaan tercatat yang terlambat menyampaikan laporan keuangan auditan per 31 Desember 2018, dan belum melakukan pembayaran denda atas keterlambatan penyampaian laporan keuangan dimaksud (www.idx.co.id, 2020). Setelah dilakukan penelitian terhadap laporan keuangan PT Nipress pada quartal tiga tahun 2018, nilai ekuitas yang dimiliki oleh PT Nipress lebih kecil dari pada nilai liabilitasnya. Ini menandakan bahwa 
perusahaan yang bergerak dalam sektor aneka industri dan komponen ini sedang mengalami kesulitan keuangan. Sejalan dengan perpanjangan penghentian sementara perdagangan efek PT Nipress oleh Bursa Efek Indonesia karena sedang dilakukan penelaahan lebih lanjut terhadap PT Nipress terkait adanya permohonan penundaan kewajiban pembayaran utang (PKPU) oleh PT Boxindo Gala Sejati terhadap PT Nipress Tbk di Pengadilan Negeri Jakarta Pusat, hal ini menimbulkan keraguan terkait keberlangsungan usaha atau going concern (bisnis.com, 2020).

Perusahaan PT. Nipress tersebut belum menyampaikan laporan keuangan ke publik sampai batas waktu yang ditentukan. Adanya permasalahan tersebut menunjukkan kurangnya kepatuhan dan kedisiplinan perusahaan pada aturan yang ada. Sehingga keterlambatan penyampaian laporan keuangan dapat menjadi masalah bagi perusahaan dan dapat menimbulkan tanggapan negatif dari para pelaku pasar modal terutama investor, oleh karena itu laporan keuangan yang sudah diaudit memiliki manfaat yang sangat penting dalam proses pengukuran dan penilaian kinerja suaitu perusahaan bagi para pengambil keputusan dimana laporan keuangan yang sudah diaudit berisi laporan posisi keuangan perusahaan, hasil usaha perusahaan, dan perubahan posisi keuanganperusahaan yang ditujukan bagi pihak internal maupun pihak eksternal.

Selanjutnya penelitian mengenai audit report lag telah banyak dilakukan, namun adanya ketidakkonsistenan pada hasil penelitian terdahulu membuat faktor-faktor yang mempengaruhi lamanya waktu yang diperlukan auditor untuk melakukan prosedur auditnya menjadi objek yang menarik dan penting untuk diteliti. Dengan mengetahui faktor-faktor yang menyebabkan audit report lag, diharapkan hal-hal yang membuat lamanya waktu audit perusahaan di Indonesia dapat diketahui dan publikasi laporan keuangan benar-benar memberikan manfaat bagi para pemakai laporan keuangan termasuk para investor (Putri, 2014).

Ada beberapa faktor yang dapat mempengeruhi audit report lag. Pada penelitian ini faktor yang diteliti adalah ukuran perusahaan, financial distress, dan audit complexity. Ukuran perusahaan mencerminkan bahwa luas perusahaan dalam menjalankan operasinya. Semakin besar perusahaan, maka semakin banyak transaksi yang terjadi di perusahaan. Hal ini mengakibatkan semakin banyak jumlah sampel yang harus diambil dan semakin luas prosedur audit yang dilakukan (Manalu, 2012). Kondisi keuangan menjadi perhatian banyak pihak, tidak hanya manajemen perusahaan karena kelangsungan hidup dan kondisi keuangan perusahaan menentukan kemakmuran berbagai pihak yang berkepentingan. Kesulitan keuangan akan menjadi berita buruk yang mempengaruhi kondisi perusahaan di mata publik. Oleh karena itu manajemen cenderung menunda penyampaian laporan keuangan yang berisi berita buruk (Budiasih \& Saputri, 2014). Kompleksitas audit merupakan kejadian dimana auditor memeriksa setiap transaksi suatu perusahaan yang memiliki cabang atau entitas anak perusahaan sehingga memerlukan waktu yang lama dalam proses ini, semakin banyak anak perusahaan maka semakin kompleks auditor dalam melakukan proses pemeriksaan. Kompleksitas audit adalah tugas yang tidak terstruktur, membingungkan dan sulit (Nirmala \& Cahyonowati, 2013).

Berdasarkan latar belakang masalah yang telah diuraikan, maka rumusan 
masalah dalam penelitian ini adalah 1) apakah ukuran perusahaan berpengaruh terhadap audit report lag. 2) apakah financial disress berpengaruh terhadap audit report lag. 3) apakah audit complexity berpengaruh terhadap audit report lag. 4) apakah ukuran perusahaan, financial distress, dan audit complexity berpengaruh secara simultan terhadap audit report lag.

\section{Teori Agensi}

Agency theory adalah hubungan atau kontrak antara principal dan agent, dimana prinsipal adalah pihak yang mempekerjakan agen agar melakukan tugas untuk kepentingan prinsipal, sedangkan agen adalah pihak yang menjalankan kepentingan prinsipal (Scott, 2015). Teori agensi menghasilkan cara yang penting untuk menjelaskan kepentingan yang berlawanan antara manajer dan pemilik yang merupakan suatu rintangan (Rusofi, 2019).

Teori keagenan menunjukkan arti pentingnya monitoring dalam hubungan antara agen dan prinsipal. Pengauditan atas laporan keuangan merupakan cara untuk memonitor kontrak antara agen dan prinsipal. Pengauditan dilakukan oleh Kantor Akuntan Publik (KAP) sebagai penjamin integritas angka-angka akuntansi yang dihasilkan oleh teknologi pihak diaudit yang digunakan dalam kontrak.

\section{Teori Kepatuhan}

Kepatuhan adalah mengikuti suatu spesifikasi, standar, atau hukum yang telah diatur dengan jelas yang biasanya diterbitkan oleh lembaga atau organisasi yang berwenang dalam suatu bidang tertentu. Teori kepatuhan menekankan pentingnya proses sosialisasi dalam mempengaruhi kepatuhan individu. Kepatuhan merupakan salah satu faktor yang berperan dalam penciptaan nilai perusahaan sehingga setiap perusahaan harus memenuhi seluruh aturan yang berlaku seperti kode etik perusahaan, aturan pemerintah, undang-undang, dan lain sebagainya (Harahap, 2011).

\section{Signaling Theory}

Signaling theory adalah teori yang menyebut bahwa suatu pihak (agent) menyampaikan informasi tentang dirinya sendiri kepada pihak lain (principal), Julien (2013). Signaling theory didasarkan pada asumsi bahwa informasi yang dipublikasikan oleh perusahaan diterima oleh para pengguna laporan keuangan atau masing-masing pihak tidak sama. Hal ini disebabkan karena adanya asimetri informasi antara pihak internal perusahaan dan pihak eksternal, sehingga perusahaan berupaya untuk mengurangi adanya asimetri informasi tersebut. Kualitas informasi dapat dinilai dari berbagai sudut pandang, yaitu keakuratan, relevan, kelengkapan informasi, dan ketepatan waktu (Setiadi, 2017).

\subsection{Pengaruh ukuran perusahaan terhadap audit report lag}

Peneliti menganalisis seberapa besar hubungan ukuran perusahaan dengan audit report lag. Berdasarkan teori kepatuhan yang menekankan pentingnya proses sosialisasi terhadap kepatuhan individu, perusahaan besar diduga akan menyelesaikan laporan keuangannya lebih cepat dibandingkan perusahaan kecil. Salah satu penyebabnya adalah perusahaan besar cenderung memiliki sistem akuntansi yang telah terstruktur dan karenanya meningkatnya efisiensi dan akurasi laporan keuangan. Justita Dura (2017) melakukan penelitian tentang ukuran perusahaan dan menyimpulkan bahwa ukuran perusahaan berpengaruh terhadap audit report lag. Fajrin (2016);Ariani\&Bawono (2018) menunjukkan ukuran perusahaan berpengaruh negatif terhadap audit 
report lag. Berdasarkan uraian teori dan hasil penelitian sebelumnya diatas maka dapat dirumuskan hipotesis sebagai berikut:

\section{H1 : Ukuran perusahaan berpengaruh signifikan dan positif terhadap audit report lag. \\ 1.2Pengaruh financial distress terhadap audit report lag}

Peneliti menganalisis seberapa besar hubungan financial distress dengan audit report lag dengan memeriksa kondisi baik atau buruk keuangan perusahaan yang dicerminkan dalam laporan keuangan. Financial distress perusahaan merupakan kondisi dimana hasil operasi perusahaan tidak cukup untuk memenuhi kewajiban perusahaan (insolvency). Baharsyah (2018) melakukan penelitian mengenai financial distress dan menunjukkan bahwa financial distress berpengaruh terhadap ketepatan waktu publikasi laporan keuangan. Berbeda dengan penelitian Julien (2013);Saed(2019) yang menunjukkan bahwa financial ditress tidak berpengaruh terhadap audit report lag. Berdasarkan uraian teori dan hasil penelitian sebelumnya diatas maka dapat dirumuskan hipotesis sebagai berikut:

\section{H2 : Financial distress berpengaruh signifikan dan positif terhadap audit report lag. \\ 1.3Pengaruh audit complexity terhadap audit report lag}

Peneliti menganalisis seberapa besar hubungan audit complexity dengan audit report lag.Audit complexity merupakan kejadian dimana auditor memeriksa setiap transaksi suatu perusahaan yang memiliki cabang atau entitas anak perusahaan sehingga memerlukan waktu yang lama dalam proses ini, berdasarkan teori agensi yaitu hubungan antara principal dan agen, semakin banyak anak perusahaan maka semakin kompleks auditor. Dalam hal ini audit complexity diukur dengan perbandingan antara persediaan dan piutang dengan total aset. Bustaman \&Kamal (2010) melakukan penelitian terhadap audit complexity dan meyimpulkan bahwa audit complexity secara parsial tidak berpengaruh signifikan terhadap audit delay. Penelitian Herawati dan Rusmayan (2019) menunjukkan bahwa audit complexity tidak berpengaruh positif terhadap audit report lag. Berdasarkan uraian teori dan hasil penelitian sebelumnya diatas maka dapat dirumuskan hipotesis sebagai berikut:

\section{H3 : Audit complexity berpengaruh signifikan dan positif terhadap audit report lag.}

\section{METODE PENELITIAN}

\subsection{Jenis Penelitian}

Jenis penelitian yang digunakan adalah kuantitatif metode deskriptif. Menurut Sugiyono (2018:37) penelitian kuantitatif adalah suatu rumusan masalah penelitian yang bersifat menanyakan hubungan antara dua variabel atau lebih.Jenis data yang digunakan dalam penelitian ini merupakan data sekunder, yaitu sumber data yang tidak langsung memberikan data kepada pengumpul data, misalnya lewat orang lain atau dokumen (Sugiyono, 2018:225). Data pada penelitian ini berupa laporan keuangan yang telah dipublikasikan dan diambil dari database Bursa Efek Indonesia selama tahun 2015-2019. Data laporan perusahaan sampel tersebut dapat diakses melalui www.idx.co.id. Variabel dependen dan independen dalam penelitian ini sebagai berikut: 


\section{a. Ukuran Perusahaan}

Ukuran perusahaan merupakan besarnya ukuran perusahaan yang diukur berdasarkan total aset. Semakin besar total aset suatu perusahaan mengindikasikan bahwa ukuran perusahaan tersebut besar, begitu juga sebaliknya. Variabel ukuran perusahaan dalam penilitian ini dihitung dengan melakukan logaritma natural atas total aset perusahaan (Nirmalasari, 2018).

$$
S I Z E=\operatorname{Ln}(\text { nilai totalaset })
$$

\section{b. Financial Distress}

Financial distress perusahaan merupakan kondisi dimana hasil operasi perusahaan tidak cukup untuk memenuhi kewajiban perusahaan (insolvency). Dalam penelitian ini variabel financial distress diproksikan dengan Debt to Asset Ratio (DAR) karena rasio total debt to asset menunjukkan seberapa besar keseluruhan hutang dapat dijamin oleh keseluruhan harta yang dimiliki oleh perusahaan. Nilai DAR merupakan nilai prediktor yang dominan dalam memprediksi kondisi financial distress karena memiliki nilai koefisien cukup signifikan, (Nurfajrina dkk, 2014). Variabel financial distress diukur dengan rasio antara total hutang dengan total aktiva (Listyaningsih dan Cahyono, 2018)

\section{c. Audit Complexity}

$$
\text { DAR }=\frac{\text { Total Hutang }}{\text { Total Aktiva }} \text { X 100\% }
$$

Audit complexity merupakan kejadian dimana auditor memeriksa setiap transaksi suatu perusahaan yang memiliki cabang atau entitas anak perusahaan sehingga memerlukan waktu yang lama dalam proses ini, semakin banyak anak perusahaan maka semakin kompleks auditor. Variabel ini diukur dengan rasio antara jumlah persediaan dan piutang dengan total aset (Nirmalasari, 2018).

\section{d. Audit Report Lag}

$$
\text { Audit Complexity }=\text { Persediaan }+ \text { Piutang }
$$

Total Aset

Menurut Dyer dan McHugh (1975), audit report lag diukur berdasarkan jumlah hari yang dibutuhkan auditor untuk menyelesaikan prosedur auditnya, dihitung menggunakan tanggal ditandatanganinya laporan audit dikurangi tanggal akhir periode akuntansi perusahaan (31 Desember) (Pramaharjan, 2015:3).

Audit Report Lag $=$ Tanggal Laporan Audit - Tanggal Laporan Keuangan

\subsection{Populasi dan Sampel}

Populasi adalah wilayah generalisasi yang terdiri atas obyek atau subyek yang mempunyai kualitas dan karakteristik tertentu yang diterapkan oleh peneliti untuk dipelajari dan kemudian ditarik kesimpulannya (Sugiyono, 2018:80). Populasi dalam penelitian ini adalah perusahaan sektor aneka industri dan subsektor minyak dan gas bumi yang terdaftar dalam Bursa Efek Indonesia (BEI) tahun 2015-2019 dengan total perusahaan sebanyak 64 perusahaan yang terdiri dari 53 perusahaan sektor aneka industri dan 13 perusahaan subsektor minyak dan gas bumi. 
Sampel adalah bagian dari jumlah dan karakteristik yang dimiliki oleh populasi tersebut (Sugiyono, 2018:81). Dengan demikian sampel adalah sebagian dari populasi yang karakteristiknya hendak diselidiki, dan bisa mewakili keseluruhan populasinya sehingga jumlahnya lebih sedikit dari populasi. Pengambilan sampel menggunakan metode purposive sampling, yaitu sampel dipilih dengan menggunakan pertimbangan tertentu yang disesuaikan dengan tujuan penelitian atau masalah penelitian yang dikembangkan.

Kriteria-kriteria yang digunakan dalam penentuan sampel penelitian, antara lain:

1. Perusahaan sektor aneka industri dan subsektor minyak dan gas bumi yang terdaftar di Bursa Efek Indonesia selama tahun 2015-2019.

2. Perusahaan sektor aneka industri dan subsektor minyak dan gas bumi yang menerbitkan annual report atau laporan keuangan dalam mata uang rupiah yang telah diaudit selama tahun 2015-2019.

3. Perusahaan sektor aneka industri dan subsektor minyak dan gas bumi yang mengalami kerugian (laba negatif) selama tahun pengamatan.

4. Memiliki setidaknya satu entitas anak (subsidiary) disertai jumlah entitas anak langsung yang dikonsolidasi.

5. Memiliiki kelengkapan data yang mendukung terhadap variabel penelitian.

\subsection{Teknik Analisis Data}

Metode analisis data dalam penelitian ini menggunakan statistik deskriptif dan analisis regresi berganda dengan bantuan software SPSS versi 25. Adapun bentuk-bentuk pengujian analisis data dalam penelitian ini, yaitu :

1. Statistik deskriptif adalah statistik yang digunakan untuk menganalisis data dengan cara mendeskripsikan atau menggambarkan data yang telah terkumpul sebagaimana adanya tanpa bermaksud membuat kesimpulan yang berlaku untuk umum atau generalisasi (Sugiyono, 2018:147).

2. Uji asumsi klasik yang terdiri dari uji normalitas, uji mulkolinearitas, uji heteroskedastisitas, dan uji autokorelasi

3. Uji regresi berganda, dalam penelitian ini analisis regresi berganda digunakan untuk memprediksi pengaruh ukuran perusahaan, financial distress, dan audit complexity terhadap audit report lag. Adapun persamaan untuk menguji hipotesis secara keseluruhan pada penelitian ini adalah sebagai berikut :

$$
\mathrm{ARL}=\alpha+\beta 1 \mathrm{SIZE}+\beta 2 \mathrm{DAR}+\beta 3 \mathrm{ACOM}+\varepsilon
$$

Keterangan:

$\begin{array}{ll}\text { ARL } & =\text { Audit Report Lag } \\ \text { SIZE } & =\text { Ukuran Perusahaan } \\ \text { DAR } & =\text { Financial Distress } \\ \text { ACOM } & =\text { Audit Complexity } \\ \text { a } & =\text { Konstanta } \\ \beta 1, \ldots, \beta 3 & =\text { Koefisien Regresi } \\ \varepsilon & =\text { Kesalahan atau error }\end{array}$

4. Uji t digunakan untuk menunjukkan seberapa jauh pengaruh satu variabel penjelas (independen) secara individual dalam menerangkan variasi variabel dependen. Jika nilai signifikansi $\mathrm{t}<0,05$; maka Ha diterima, yang berarti menunjukkan bahwa variabel independen secara individual berpengaruh terhadap variabel dependen. 
5. Uji statistik F digunakan untuk menguji hipotesis bahwa setiap variabel independen secara bersama-sama berpengaruh terhadap variabel dependen. Pengujian ini dibuktikan dengan membandingkan nilai signifikansi $F$ hasilpengujian dengan tingkat signifikansi. Jika nilai signifikansi $F<0.05$; maka Ha diterima, yang berarti menunjukkan bahwa variabel independen secara simultan berpengaruh terhadap variabel independen.

6. Koefisien Determinasi merupakan analisis Adjusted $R^{2}$ yang digunakan untuk mengukur seberapa jauh kemampuan model dalam, menerangkan variasi variabel dependen.

\section{HASIL DAN PEMBAHASAN}

\subsection{Hasil Penelitian}

\section{Statistik Deskriptif}

Analisis statistik deskriptif digunakan untuk menggambarkan data yang telah terkumpul tanpa bermaksud membuat kesimpulan yang berlaku untuk umum yang meliputi nilai minimum, nilai maksimum, nilai rata-rata (mean), dan standar deviasi dari masing-masing variabel. Di bawah ini adalah hasil statistik deskriptif dalam penelitian ini:

Tabel 1 Hasil Uji Statistik Deskriptif Descriptive Statistics

\begin{tabular}{lrrrrr}
\hline & N & Minimum & Maximum & Mean & $\begin{array}{l}\text { Std. } \\
\text { Deviation }\end{array}$ \\
\hline SIZE & 22 & 24.77 & 31.34 & 28.20 & 2.13 \\
DAR & 22 & 0.09 & 1.20 & 0.69 & 0.20 \\
ACOM & 22 & 0.05 & 0.57 & 0.33 & 0.17 \\
ARL & 22 & 66.00 & 97.00 & 85.14 & 6.14 \\
Valid N & 22 & & & & \\
(listwise) & & & & & \\
\hline
\end{tabular}

Sumber: data diolah (2020)

Dari tabel 1 menunjukkan bahwa nilai rata-rata (mean) paling tinggi adalah audit report lag sebesar 85,14 sedangkan nilai rata-rata (mean) yang paling rendah adalah audit complexity sebesar 0,33. Nilai standar deviasi tertinggi adalah audit report lag sebesar 6,14, sedangkan niai terendah adalah audit complexity sebesar 0,17.

2. Uji Asumsi Klasik

Uji normalitas digunakan untuk menguji apakah nilai residual yang dihasilkan dari regresi terdistribusi secara normal atau tidak. Dalam penelitian ini menggunakan uji statistik Kolmogorov-smirnov (K-S). Jika Sig > 0,05 maka data berdistribusi normal. 
Tabel 2 One-Sample Kolmogorov-Smirnov Test

\begin{tabular}{llr}
\hline & & \multicolumn{1}{c}{$\begin{array}{c}\text { Unstandardized } \\
\text { Residual }\end{array}$} \\
$\mathrm{N}$ & Mean & 22 \\
Normal Parameters & .0000000 \\
& Std. Deviation & 4.43662586 \\
Most Extreme Differences & Absolute & .113 \\
& Positive & .076 \\
& Negative & -.113 \\
Test Statistic & & .113 \\
Asymp. Sig. (2-tailed) & & $.200^{\mathrm{c}, \mathrm{d}}$ \\
\hline Sumber : Diolah menggunakan SPSS 25 (2020)
\end{tabular}

Dari tabel 2 menunjukkan bahwa nilai Asymp. Sig. (2-tailed) sebesar 0,200 yang berarti tingkat signifikan lebih besar dari pada 0,05 yaitu 0,200>0,05. Dengan demikian dapat disimpulkan bahwa dalam penelitian ini data terdistribusi secara normal.

3. Uji Multikolinearitas

Uji multikolinearitas digunakan untuk menguji apakah dalam model regresi ditemukan adanya korelasi antar variabel bebas. Model regresi yang baik seharusnya tidak terjadi korelasi antara variabel bebas. Pengujian terhadap ada tidaknya multikolinearitas dilakukan dengan metode VIF (Variance Inflation Factor). Berikut ini adalah hasil dari uji multikolinearitas.

Tabel 3 Uji Multikolinearitas

Coefficients

\begin{tabular}{llcr}
\hline & Mode1 & \multicolumn{2}{c}{ Collinearity Statistics } \\
\cline { 3 - 4 } 1 & & Tolerance & VIF \\
& (Constant) & .817 & 1.225 \\
& SIZE & .953 & 1.049 \\
& DAR & .806 & 1.241 \\
\hline
\end{tabular}

Sumber : Diolah menggunakan SPSS 25 (2020)

Berdasarkan hasil output SPSS pada tabel 3 dapat dijelaskan bahwa seluruh variabel independen dalam penelitian ini memiliki nilai tolerance diatas 0,10 dan nilai VIF yang dimiliki kurang dari 10. Sehingga dapat disimpulkan bahwa untuk variabel independen dalam penelitian ini yang terdiri dari ukuran perusahaan, financial distress, dan audit complexity tidak mengalami multikolinearitas.

4. Uji Heteroskedastisitas

Uji heteroskedastisitas bertujuan untuk menguji apakah dalam model regresi terjadi ketidaksamaan variance dari residual satu pengamatan ke pengamatan lain. Berikut ini adalah hasil dari uji heteroskedastisitas dengan uji scatterplot. 
Tabel 4 Uji Glejser

\begin{tabular}{|c|c|c|c|c|c|c|}
\hline \multicolumn{7}{|c|}{ Coefficientsa } \\
\hline \multirow{3}{*}{\multicolumn{2}{|c|}{ Model }} & \multicolumn{2}{|c|}{$\begin{array}{l}\text { Unstandardized } \\
\text { Coefficients }\end{array}$} & \multirow{3}{*}{$\begin{array}{c}\text { Standardized } \\
\text { Coefficients } \\
\text { Beta }\end{array}$} & \multirow[t]{3}{*}{$\mathrm{t}$} & \multirow[t]{3}{*}{ Sig. } \\
\hline & & $\mathrm{B}$ & Std. & & & \\
\hline & & & Error & & & \\
\hline 1 & (Constant) & -7.967 & 9.165 & & -.869 & .396 \\
\hline & SIZE & .447 & .346 & .323 & 1.293 & .212 \\
\hline & DAR & -.715 & 3.442 & -.048 & -.208 & .838 \\
\hline & $\mathrm{ACOM}$ & -2.485 & 4.555 & -.137 & -.546 & .592 \\
\hline
\end{tabular}

Sumber : Diolah menggunakan SPSS 25 (2020)

Berdasarkan tabel 4 di atas menunjukkan hasil nilai signifikansi diatas 0,05 yaitu variabel ukuran perusahaan sebesar 0.212, financial distress sebesar 0,838, dan audit complexity sebesar 0,592. Maka dapat disimpulkan bahwa data tersebut tidak terjadi heteroskedastisitas.

5. Uji Autokorelasi

Uji autokorelasi bertujuan untuk menguji apakah dalam suatu model regresi berganda ada korelasi antara kesalahan pengganggu pada periode $t$ dengan kesalahan pengganggu pada periode t-1 (Sugiyono, 2018). Model regresi yang baik adalah tidak terjadi autokorelasi.

Tabel 5 Uji Autokolerasi

\begin{tabular}{|c|c|c|c|c|c|}
\hline \multicolumn{6}{|c|}{ Model Summaryb } \\
\hline Model & $\mathrm{R}$ & $\begin{array}{l}\mathrm{R} \\
\text { Squa } \\
\text { re }\end{array}$ & $\begin{array}{c}\text { Adjusted } \\
\text { R } \\
\text { Square }\end{array}$ & $\begin{array}{l}\text { Std. Error of } \\
\text { the Estimate }\end{array}$ & $\begin{array}{l}\text { Durbin- } \\
\text { Watson }\end{array}$ \\
\hline 1 & $.630^{a}$ & .397 & .296 & 4.79210 & 2.173 \\
\hline
\end{tabular}

Sumber : Diolah menggunakan SPSS 25 (2020)

Berdasarka hasil uji SPSS 25 pada tabel 5 di atas dapat dilihat bahwa nilai Durbin-Watson (DW) yang diperoleh sebesar 2,173. Nilai dL dan dU yang diperoleh dari tabel Durbin-Watson dengan jumlah data $(\mathrm{n})=22$ dan variabel independen $(\mathrm{k})=3$ maka diperoleh niai $\mathrm{dL}=1,0529$ dan $\mathrm{dU}=1,6640$. Berdasarkan kriteria yang telah ditetapkan dimana nilai dU lebih kecil dari nilai DW dan nilai DW lebih kecil dari 4-dU $(1,6640<2,173<2,336)$ atau $\mathrm{dU}<\mathrm{DW}<$ 4-dU. Sehingga dapat disimpulkan bahwa tidak terjadi autokorelasi pada model regresi.

6. Uji Regresi Berganda

Analisis regresi berganda dalam penelitian ini digunakan untuk menguji variabel independen yaitu ukuran perusahaan, financial distress, dan audit complexity terhadap variabel dependen audit report lag. Uji ini digunakan untuk mengetahui pengaruh atau hubungan antara dua atau lebih variabel independen dengan satu variabel dependen dalam penelitian ini. 


\begin{tabular}{|c|c|c|c|}
\hline \multirow[t]{2}{*}{ Model } & \multicolumn{2}{|c|}{$\begin{array}{l}\text { Unstandardized } \\
\text { Coefficients }\end{array}$} & \multirow{2}{*}{$\begin{array}{c}\text { Unstandardized } \\
\text { Coefficients } \\
\text { Beta }\end{array}$} \\
\hline & B & $\begin{array}{l}\text { Std. } \\
\text { Error }\end{array}$ & \\
\hline (Constant) & 126.009 & 14.428 & \\
\hline SIZE & -1.72 & 0.544 & -0.64 \\
\hline DAR & 2.405 & 5.418 & 0.083 \\
\hline ACOM & 18.205 & 7.172 & 0.518 \\
\hline
\end{tabular}

Sumber : Diolah menggunakan SPSS 25 (2020)

Berdasarkan tabel 6 diatas menunjukkan bahwa hasil uji linier berganda dapat dikembangkan dengan menggunakan model persamaan regresi linier berganda yaitu :

$$
Y=126.009-1.720 x 1+2.405_{x 2}+18.205_{x 3}+e
$$

Nilai konstanta yang dihasilkan sebesar 126.009. Hal ini dapat diartikan bahwa jika variabel independen yaitu ukuran perusahaan, financial distress, dan audit complexity konstan, maka besarnya audit report lag adalah sebesar 126.009

7. Uji t

Uji statistik t digunakan untuk menunjukkan seberapa jauh pengaruh satu variabel independen secara individual dalam menerangkan variasi variabel dependen. Nilai t-statistik dapat diketahui dengan tabel yang memiliki signifikansi $5 \%$ derajat kebebasan $\mathrm{df}=(\mathrm{n}-\mathrm{k})$ dan $(\mathrm{k}-1)$, dimana $\mathrm{n}$ adalah jumlah observasi. Bila $\mathrm{t}$ memiliki nilai signifikan $<0,05$ maka $\mathrm{H}_{0}$ ditolak, artinya terdapat pengaruh yang signifikan antara satu variabel independen terhadap variabel dependen.

Tabel 7 Uji Parsial (Uji t)

\begin{tabular}{|c|c|c|c|c|c|}
\hline \multicolumn{6}{|c|}{ Coefficients $^{a}$} \\
\hline \multirow[t]{2}{*}{ Model } & \multicolumn{2}{|c|}{$\begin{array}{l}\text { Unstandardized } \\
\text { Coefficients }\end{array}$} & \multirow{2}{*}{$\begin{array}{c}\text { Standardized } \\
\text { Coefficients } \\
\text { Beta }\end{array}$} & \multirow[t]{2}{*}{$\mathrm{t}$} & \multirow[t]{2}{*}{ Sig. } \\
\hline & $\mathrm{B}$ & $\begin{array}{l}\text { Std. } \\
\text { Error }\end{array}$ & & & \\
\hline 1Constant) & 126.009 & 14.428 & & 8.733 & .000 \\
\hline SIZE & -1.720 & .544 & -.640 & -3.160 & .005 \\
\hline DAR & 2.405 & 5.418 & .083 & .444 & .662 \\
\hline ACOM & 18.205 & 7.172 & .518 & 2.538 & .021 \\
\hline
\end{tabular}

Sumber : Diolah menggunakan SPSS 25 (2020)

Dari hasil analisis menggunakan SPSS 25 yang terdapat pada tabel 7 menunjukkan ukuran perusahaan mempunyai nilai signifikan sebesar 0,005 yang berarti lebih kecil dari pada 0,05. Nilai t hitung yang diperoleh sebesar 3,160 dengan t tabel 2,10092. Sehingga dapat disimpulkan bahwa H1 diterima 
yang menyatakan bahwa terdapat pengaruh yang signifikan antara variabel ukuran perusahaan terhadap audit report lag. Dari hasil perhitungan variabel financial distress mempunyai nilai signifikan sebesar 0,662 yang berarti lebih besar dari pada 0,05. Nilai t hitung yang diperoleh sebesar 0,444 dengan nilai $t$ tabel yang diperoleh 2,10092. Sehingga dapat disimpulkan bahwa H2 ditolak yang menyatakan bahwa tidak terdapat pengaruh signifikan antara variabel financial distress terhadap audit report lag. Pada perhitungan variabel audit complexity mempunyai nilai signifikan sebesar 0,021 yang berarti lebih kecil dari pada 0,05. Nilai t hitung yang diperoleh sebesar 2,538 dengan t tabel sebesar 2,10092. Sehingga dapat disimpulkan H3 diterima yang menyatakan bahwa terdapat pengaruh yang signifikan antara variabel audit complexity terhadap audit report lag.

8. Uji Koefisien Determinasi $\left(\mathrm{R}^{2}\right)$

Uji koefisien determinasi $\mathrm{R}^{\mathbf{2}}$ digunakan untuk mengukur seberapa jauh kemampuan model dalam menerangkan variasi variabel dependen. Hasil uji koefisien deterinasi dapat dilihat pada tabel 8 dibawah ini:

Tabel 8 Koefisien Determinasi $\left(\mathbf{R}^{2}\right)$

\begin{tabular}{|c|c|c|c|c|}
\hline \multicolumn{5}{|c|}{ Model Summaryb } \\
\hline Model & $\mathrm{R}$ & $\begin{array}{l}\mathrm{R} \\
\text { Square }\end{array}$ & $\begin{array}{l}\text { Adjusted } \\
\text { R Square }\end{array}$ & $\begin{array}{l}\text { Std. Error of } \\
\text { the Estimate }\end{array}$ \\
\hline 1 & $.630^{a}$ & .397 & .296 & 4.79210 \\
\hline
\end{tabular}

Sumber : Diolah menggunakan SPSS 25 (2020)

Berdasarkan tabel 8 di atas dapat dilihat bahwa nilaiAdjusted $R$ Square sebesar 0,296 hal ini berarti bahwa 29,6\% variabel audit report lag dapat dipengaruhi oleh variabel ukuran perusahaan, financial distress, dan audit complexity sedangkan sisanya dipengaruhi oleh variabel lain yang tidak diteliti dalam penelitian ini seperti opini audit, jenis industry, reputasi KAP, audit tenure dan lain sebagainya.

\subsection{Pembahasan}

1. Pengaruh Ukuran Perusahaan terhadap Audit Report Lag

Hasil pengujian variabel ukuran perusahaan dalam penelitian ini berpengaruh terhadap audit report lag, hal ini dapat dilihat dari nilai signifikan yang diperoleh sebesar 0,005 lebih kecil dari 0,05 sehingga hipotesis pertama (H1) diterima. Hal ini dapat disebabkan karena adanya kewajiban bagi perusahaan untuk menyampaikan laporan keuangan auditan kepada otoritas jasa keuangan paling lambat pada akhir bulan keempat setelah tahun buku berakhir sehingga membuat manajemen perusahaan akan berusaha menyelesaikan proses auditnya lebih cepat. Keterkaitan antar variabel dapat dilihat dari perusahaan besar dengan total asset yang lebih besar juga dapat menyelesaikan audit lebih lama dibandingkan dengan perusahaan yang mempunyai total asset lebih kecil. Hal ini disebabkan oleh kuantitas sampel yang harus diambil semakin besar dan prosedur audit yang harus ditempuh semakin banyak. Dalam mengukur suatu perusahaan dapat didasarkan pada nilai buku aset yang dimiliki perusahaan.Semakin besar ukuran suatu perusahaan maka semakin rumit pula proses dalam melakukan auditnya. Terkait komponen dalam audit report lag, ukuran perusahaan mempengaruhi seluruh komponen baik scheduling, fieldwork, dan reporting lag. Penelitian ini 
mendukung hasil penelitian yang dilakukan oleh Didipu (2016);Ariani\&Bawono (2018) yang menyatakan bahwa ukuran perusahaan berpengaruh terhadap audit report lag.

Hasil penelitian ini berbeda dengan penelitian yang dilakukan oleh Sastrawan \& Latrini (2016), karena hasil penelitian tersebut menemukan bahwa ukuran perusahaan tidak berpengaruh terhadap audit report lag. Hal ini dapat terjadi karena perusahaan yang memiliki jumlah aset yang besar tidak memiliki alasan untuk menunda penerbitan laporan keuangan auditannya karena ini dianggap sebagai berita baik yang mampu meningkatkan kredibilitas perusahaan. Dalam proses pengauditan laporan keuangan suatu perusahaan, bukan hanya aset yang menjadi faktor utama yang mempengaruhi panjang atau pendeknya audit report lag, hal ini bisa diakibatkan karena adanya masalah perusahaan, keterlambatan informasi, supply data serta pengalaman auditor. Lamanya pemberian data-data yangdibutuhkan dalam proses audit dan lamanya penyampaian informasi yang diberikan sehingga mempersulit auditor dalam melaksanakan tugasnya.

\section{Pengaruh Financial Distress Terhadap Audit Report Lag}

Hasil pengujian variabel financial distress dalam penelitian ini tidak berpengaruh terhadap audit report lag, hal ini dapat dilihat dari nilai signifikan yang diperoleh 0,662 lebih besar dari 0,05 sehingga hipotesis kedua (H2) ditolak. Hal ini mengindikasikan bahwa kesulitan keuangan (financial distress) yang dialami oleh perusahaan baik dalam pengertian kas ataupun modal kerja tidak mempengaruhi audit report lag pada perusahaan sektor industri dan subsektor minyak dan gas bumi yang terdaftar di Bursa Efek Indonesia tahun 2015-2019. $\mathrm{Hal}$ ini dapat terjadi dikarenakan financial distress terjadi sebelum kebangkrutan. Kondisi financial distress yang terjadi pada perusahaan dapat meningkatkan resiko audit pada auditor independen, khususnya resiko pengendalian dan resiko deteksi. Selain itu sesuai standar professional akuntan publik melaksanakan prosedur audit perusahaan baik yang memiliki liabilitas besar atau perusahaan dengan liabilitas kecil tidak akan mempengaruhi proses penyelesaian audit laporan keuangan, karena auditor yang ditunjuk sudah pasti telah menyediakan waktu sesuai dengan kebutuhan jangka waktu untuk menyelesaikan proses pengauditan liabilitas. Keterkaitan antar variabel dapat dilihat dari tingkat DAR tinggi namun perusahaan tidak dapat dikatakan dalam kondisi financial distress dikarenakan perusahaan seperti perbankan jika memiliki tingkat hutang yang tinggi ini telah menjadi hal yang wajar karena sebagian besar dana perusahaan adalah memang berasal dari dana pihak ketiga, dimana dana yang berasal dari pihak ketiga tersebut nantinya akan dijadikan sebagai jaminan yang diberikan Bank kepada pihak lain, sehingga hal ini yang menyebabkan nilai hutang di perusahaan menjadi tinggi dan tingkat hutang yang tinggi ini tidak mempengaruhi lamanya auditor dalam melakukan audit. Jika Bank telah mengelola manajemen risiko dengan baik, maka hal ini tidak akan meningkatkan risiko audit pada perusahaan. Penelitian ini konsisten dengan penelitian yang dilakukan oleh Saed (2019); Julien (2013) yang menyatakan bahwa financial distress tidak berpengaruh terhadap audit report lag.

Hasil penelitian ini berbeda dengan penelitian yang dilakukan oleh Sawitri \& Budiartha (2018) yang menyatakan bahwa financial distress berpengaruh terhadap audit delay. Hal ini bisa disebabkan karena audit report 
lag akanbertambah ketika laporan keuangan mengalami proses penundaan. Penundaan ini terjadi karena adanya berita buruk dalam laporan keuangan yaitu financial distress, sehingga membuat manajemen berusaha mengurangi berita buruk pada laporan keuangan perusahaan. Kondisi financial distress pada perusahaan dapat menigkatkan resiko audit. Dengan meningkatnya resiko audit, maka auditor harus melakukan pemeriksaan resiko dan menunda proses audit yang berdampak terhadap audit report lag.

\section{Pengaruh Audit Complexity Terhadap Audit Report Lag}

Hasil pengujian variabel audit complexity dalam penelitian ini berpengaruh signifikan terhadap audit report lag, hal ini dapat dilihat dari nilai signifikan yang diperoleh sebesar 0,021 lebih kecil dari 0,05 sehingga hipotesis ketiga (H3) diterima. Dalam penelitian yang dilakukan oleh peneliti menunjukkan bahwa audit complexity berpengaruh terhadap audit report lag dibuktikan dengan nilai sig yang diperoleh $2,1 \%$. Semakin tinggi audit complexity suatu perusahaan semakin rendah pula tingkat ketepatan waktu audit perusahaan (Nirmalasari, 2018).

Keterkaitan antar variabel bahwa Audit complexity berpengaruh pada audit report lag karena hasil penelitian menunjukkan adanya pengaruh yang signifikan antara kompleksitas perusahaan dengan audit report lag. Hal ini mungkin disebabkan karena auditor independen melaksanakan kewajiban profesionalnya dipengaruhi kompleksitas operasi yang ada pada perusahaan yang diaudit. Potensi audit report lag yang lebih panjang, didasari oleh anggapan bahwa perusahaan dengan kompleksitas operasi yang tinggi maupun anak perusahaan yang lebih banyak akan cenderung menyelesaikan auditnya lebih lama.

Penelitian ini berbeda dengan penelitian yang dilakukan oleh Setiadi (2017);Herawaty\&Rusmawan (2019) yang menyatakan bahwa audit complexity tidak berpengaruh terhadap audit report lag. Hal ini dapat terjadi karena kecenderugan perusahaan besar yang memiliki tingkat kompleksitas yang tinggiakan lebih memilih KAP dengan sumber daya yang besar sehingga dapat mengihindari proses audit yang lebih lama.

\section{PENUTUP}

Penelitian ini dapat memberikan kesimpulan bahwa pertama,ukuran perusahaan berpengaruh terhadap audit report lag. Hasil ini menunjukkan bahwa banyaknya transaksi yang terjadi di perusahaan mengakibatkan semakin banyak jumlah sampel dan semakin luas prosedur audit yang dilakukan. Kedua, financial distress tidak berpengaruh terhadap audit report lag. Hasil ini menunjukkan bahwa kesulitan keuangan yang terjadi pada perusahaan tidak menjadi faktor keterlambatan penyampaian laporan keuangan kepada publik. Ketiga, audit complexityberpengaruh terhadap audit report lag. Hasil ini menunjukan bahwa tingkat kerumitan dalam proses audit yang dilakukan oleh auditor dapat mempengaruhi waktu yang dibutuhkan auditor dalam melakukan audit sehingga menyebabkan adanya penundaan penyampaian laporan keuangan.

Berdasarkan kesimpulan dan hasil penelitian yang telah dikemukakan diatas, maka saran-saran atau kontibusi bagi pihak investor sebagai bahan pertimbangan dalam melakukan analisis untuk melakukan investasi agar dapat memahami keadaan dimana terjadi keterlambatan laporan keuangan sebagai 
informasi sehingga para investor dapat mengurangi resiko yang terjadi dimasa mendatang. Bagi perusahaan, sebagai bahan pertimbangan untuk melakukan audit dan analisis berkala terhadap ukuran perusahaan dan audit complexity berkaitan dengan audit report lag, sehingga perusahaan dapat menghindari terjadinya audit report lag karena ketepatan waktu dalam menyampaikan laporan keuangan dan untuk penelitian selanjutnya disarankan untuk dapat memperluas populasi yang digunakan, tidak hanya fokus pada perusahaan sektor aneka industri dan subsektor minyak dan gas bumi, sehingga dapat diperoleh hasil yang lebih baik mendekati kondisi sebenarnya.

\section{DAFTARPUSTAKA}

Agoes, S. (2016). Auditing. Edisi Keenam. Buku 1. Jakarta: Salemba Empat.

Ariani, K. R., \& Bawono, A. D. B. (2018). Pengaruh Umur Dan Ukuran Perusahaan Terhadap Audit Report Lag Dengan Profitabilitas Dan Solvabilitas Sebagai Variabel Moderating. Riset Akuntansi Dan Keuangan Indonesia, 3(2), 118-126. https://doi.org/10.23917/reaksi.v3i2.6878

Arianti, BF. (2019). Analisis Pengaruh Kompleksitas Audit, Leverage dan Resiko Kredit Terhadap Fee Auditor Eksternal. Unes Journal of Economics Scienties Vol.2 Issue.1.

Bustamam, B., \& Kamal, M. (2010). Pengaruh Leverage, Subsidiaries Dan Audit Complexity terhadap Audit Delay (Studi Empiris Pada Perusahaan Manufaktur Di Bursa Efek Indonesia). Jurnal Telaah Dan Riset Akuntansi, 3(2), 110-122.

Dura, J. (2018). Pengaruh Profitabilitas, Likuiditas, Solvabilitas, Dan Ukuran Perusahaan Terhadap Audit Report Lag Pada Perusahaan Yang Terdaftar Di Bursa Efek Indonesia. Jurnal Mmiah Bisnis Dan Ekonomi Asia, 11(1), 64-70. https://doi.org/10.32812/jibeka.v11i1.34

Didipu, (2016). Pengaruh Ukuran Kantor Akuntan Publik, Ukuran Perusahaan, dan Kompleksitas Operasi Perusahaan Terhadap Audit Report Lag. Skripsi. Universitas Hasanuddin

Gudono, 2017, Teori Organisasi, CV Andi Offset : Yogyakarta.

Herawaty, V., \& Rusmawan, M. F. (2019). Pengaruh Audit Firm Status, Adit Complexity, Kepemilikan Keluarga, Dan Loss Terhadap Audit Report Lag Dengan Spesialisasi Industri Sebagai Variabel Moderasi. Prosiding Seminar Nasional Pakar Ke 2 Tahun 2019, 2, 2.39.1-2.39.6.

Julien, R. F. (2013). Pengaruh Tingkat Profitabilitas, Financial Distress, dan Pelaporan Rugi Bersih Klien Terhadap Audit Report Lag Perusahaan Manufaktur yang Terdaftar di Bursa Efek Indonesia. Skripsi, 3.

Listyaningsih, D. F., \& Cahyono, Y. T. (2018). Pengaruh Karakteristik Perusahaan Dan Financial Distress Terhadap Audit Delay ( Studi Empiris Perusahaan Manufaktur Terdaftar di BEI ). 67-78.

Mayangsari,S., \& Wandanarum. (2013). Auditing. Jakarta: Media Bangsa

Nirmala, R. P. A., \& Cahyonowati, N. (2013). Pengaruh Independensi, Pengalaman, Due Professional Care, Akuntabilitas, Kompleksitas, dan Time Budget Pressure Terhadap Kualitas Audit. Diponegoro Journal of Accounting, 2, 1-13.

Nirmalasari. (2018). Pengaruh Profitabilitas, Leverage, Ukuran Perusahaan Dan Audit Complexity Terhadap Ketepatan Waktu Audit Pada Perusahaan Manufaktur Yang Terdaftar Di Bei Periode 2013 - 2015. Jurnal Kajian 
Ekonomi Dan Kebijakan Publik, 3(2), 121-132.

Nurfajrina, A. (2016). Analisis Financial Distress Pada Perusahaan Agribisnis Di Bursa Efek Indonesia. Jurnal Keuangan Dan Perbankan, 2O(3), 448-457.

Pramaharjan, B., \& Cahyonowati, N. (2015). Faktor Faktor Yang Berpengaruh Terhadap Audit Report Lag Pada Perusahaan Manufaktur. Diponegoro Journal of Accounting, 4(4), 254048.

Sastrawan, I., \& Latrini, M. (2016). Pengaruh Profitabilitas, Solvabilitas, Dan Ukuran Perusahaan Terhadap Audit Report Lag Pada Perusahaan Manufaktur. E-Jurnal Akuntansi Universitas Udayana, 17(1), 311-337.

Stie, S., Bangsa, K., \& Bangsa, S. K. (2018). Pengaruh Ukuran Perusahaan, Pergantian Auditor dan Komite Audit Terhadap Kualitas Audit (Studi Empiris pada Perusahaan Manufaktur Sektor Industri Barang Konsumsi yang Terdaftar Di Bursa Efek Indonesia Tahun 2014-2017). 1.

Sugiyono. (2018). Metode Penelitian Pendidikan pendekatan Kuantitatif, Kualitatif, dan R\&D. Bandung: Alfabeta 